\title{
Species richness and conservation priority of dragonflies in the Suranadi Ecotourism Area, Lombok, Indonesia
}

\author{
MOHAMMAD LIWA ILHAMDI ${ }^{1, \boldsymbol{v}}$, AGIL AL IDRUS ${ }^{1}$, DIDIK SANTOSO ${ }^{1}$, GITO HADIPRAYITNO ${ }^{1}$, \\ MUHAMMAD SYAZALI ${ }^{2}$ \\ ${ }^{1}$ Department of Biology Education, Faculty of Teacher Training and Education Science, Universitas Mataram. Jl. Majapahit 62, Mataram 83125, West \\ Nusa Tenggara, Indonesia. Tel./fax.: +62-370-623873. ^email: liwa_ilhamdi@unram.ac.id \\ ${ }^{2}$ Department Elementary of School Teacher Education, Faculty of Teacher Training and Education Science, Universitas Mataram. J1. Majapahit 62, \\ Mataram 83125, West Nusa Tenggara, Indonesia
}

Manuscript received: 2 February 2021. Revision accepted: 20 March 2021.

\begin{abstract}
Ilhamdi ML, Idrus AA, Santoso D, Hadiprayitno G, Syazali M. 2021. The species richness and conservation priority of dragonflies in the Suranadi Ecotourism Area, Lombok, Indonesia. Biodiversitas 22: 1846-1852. Dragonflies are insects that have attractive colors and play an important role to balance ecosystems. They also act as bioindicators of the aquatic environment. The purpose of this study was to investigate the species richness and conservation priorities of dragonflies in the Suranadi Ecotourism Area, Lombok, Indonesia, expecting that the dragonflies will be used as charismatic species to support ecotourism. The research was conducted in August-December 2020 by surveying transect lines across 9 types of habitat. We then determined the conservation priority for each species found by referring to the Government Regulation using scoring method through a Focus Group Discussion (FGD) involving five experts. The score for each species was determined based on the percentage of the opinion from the experts. We found 18 dragonfly species from 2 suborders (Zygoptera and Anisoptera) and 5 families (Chlorocyphidae, Coenagrionidae, Platycnemididae, Aeshnidae and Libellulidae). The habitat type that supports the highest species richness was the waterway and irrigation (16 species), while the lowest species richness was found in the areas inside the forest habitat ( 2 species). The species that had the highest conservation priority scores were Pseudagrion pilidorsum declaratum, Libellago lineata, and Gynacantha subinterrupta. These three species can be used as conservation priority species in the ecotourism area of Suranadi, Lombok, Indonesia.
\end{abstract}

Keywords: Conservation priority, dragonflies, species richness

\section{INTRODUCTION}

Dragonflies play an important role as trophic components in ecosystems. As predators and prey, dragonflies are key elements in the process of transferring matter and energy along with the trophic web. Adult dragonflies prey on larger dragonflies, spiders, and various types of vertebrate animals such as frogs and birds (Rüppell et al. 2020). Also, adult dragonflies prey on various types of small animals, especially insects such as bees (Arbeiter et al. 2014). Some dragonfly species are cannibals by preying on members of the same species. In several cases, the larval phase that lives in waters becomes a predator of various other smaller animals, such as Anura larvae and mosquito larvae (Weterings et al. 2015; Linares et al (2016). Their prey, which consists of several types of harmful insects - insect pests and disease vectors - makes dragonflies act as agents of biological control (May 2019).

The important role of dragonflies can also be viewed from the aspect of environmental biology. The biotic and abiotic conditions required by dragonflies make it possible to use them as bio-indicator of environmental conditions of habitat, especially for aquatic ecosystems (Nasirian and Irvine 2017). Several parameters have been used when employing dragonflies as bioindicators, such as: the presence or absence of dragonfly species (Ting et al. 2018), the abundance ratio of Anisoptera and Zygoptera (OliveiraJunior and Juen 2019), and the ratio of the Libellulidae family against other families in Anisoptera and the ratio of the Coenagrionodae family to other families in Zygoptera (Šigutováa et al. 2019). Dragonflies can also become tourist objects because of their attractive and varied colors, and conspicuous behaviors.

Because of the important roles of dragonflies in ecosystems, there is a need to conserve the diversity and population of dragonfly. The first step toward dragonfly conservation efforts and what species to be prioritized is the availability of data about species richness. This information is essential because each species has a different endemicity, population status, and threat. Likewise, each dragonfly species has specific habitat conditions, making it requires unique management interventions.

The Suranadi Ecotourism Area is one of tourist areas located in West Lombok District, Indonesia established through Regulation No. 41 of 2016. This area consists of various habitats suitable for dragonflies. Water, which is a very important environmental component for dragonflies (Mafuwe and Moyo 2020), is available in abundance, scattered in many points and available almost all year round. Due to this condition, this area is known as "the city of water", which is considered the main tourist attraction of the area. Water with suitable characteristics can be used by 
adult dragonflies for oviposition and as habitat for larval development (Luke et al. 2017). Because of the life cycle that occurs in terrestrial and aquatic ecosystems, dragonflies have a very important role in these two habitats. Based on these situations and conditions, we conducted research in several types of habitat in the Suranadi Ecotourism Area with the aim to determine species richness of dragonflies and propose conservation priorities according to several considerations. We expect, the collected data can be used as baseline information for developing dragonfly conservation strategies as well as contributing to ecotourism activities in the Suranadi Ecotourism Area.

\section{MATERIALS AND METHODS}

\section{Study period and area}

The research was conducted from August to December 2020 in the Suranadi Ecotourism Area, Lombok, Indonesia (Figure 1). The investigated area consisted nine sampling stations, each presenting a different habitat type, namely forest edges (FE), middle forest (MF), waterways (WW), roads (RO), irrigation (IR), fields (FD), rice fields (RF), parks (PR), and pond (PO). The waterway is referred to as an area for water flows in Suranadi Ecotourism Area. The water originates from a spring and is a tributary of a river that flows continuously throughout the year. Habitat type of FE, MF, RO, FD, and PR is terrestrial habitat, while habitat type of WW, IR, RF, and PO is aquatic habitat. The characteristics of each sampling location are presented in Table 1 .

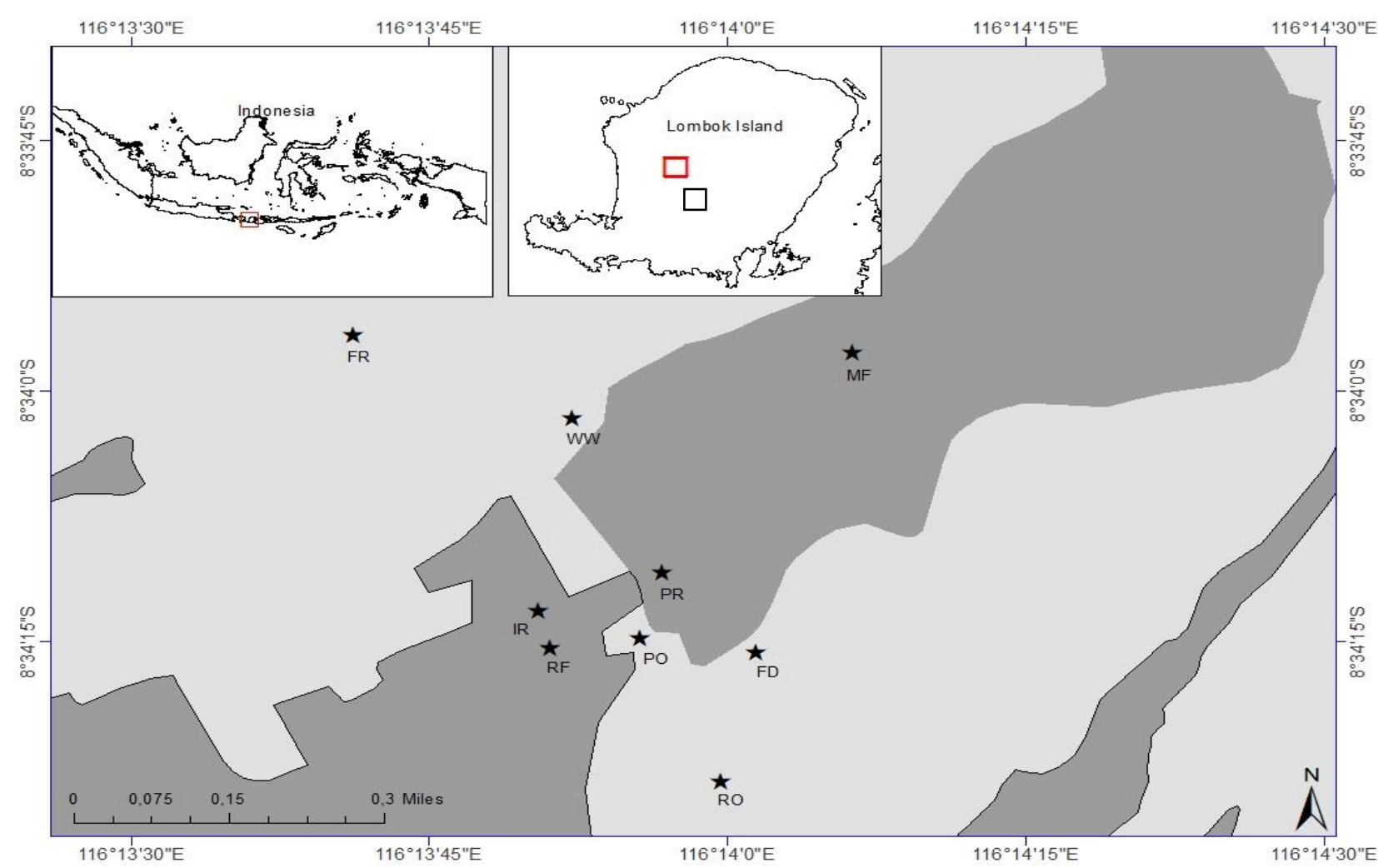

Figure 1. Map of the research location in the Suranadi Ecotourism Area, Lombok, West Nusa Tenggara, Indonesia

Table 1. The characteristics of nine habitat types in the Suranadi Ecotourism Area, Lombok, West Nusa Tenggara, Indonesia

\begin{tabular}{lccccccc}
\hline \multirow{2}{*}{$\begin{array}{c}\text { Habitat } \\
\text { Type }\end{array}$} & $\begin{array}{c}\text { Light } \\
\text { intensity }(\mathbf{C d})\end{array}$ & $\begin{array}{c}\text { Humidity } \\
(\boldsymbol{\%})\end{array}$ & $\begin{array}{c}\text { Air temp. } \\
\left({ }^{\circ} \mathbf{C}\right)\end{array}$ & $\begin{array}{c}\text { Tree canopy } \\
(\boldsymbol{\%})\end{array}$ & $\begin{array}{c}\text { Herbaceous } \\
\text { plant cover }(\boldsymbol{\%})\end{array}$ & $\begin{array}{c}\text { Altitude } \\
(\mathbf{m} \text {. asl) }\end{array}$ & $\begin{array}{c}\text { Number of plant } \\
(\mathbf{s p e c i e s})\end{array}$ \\
\hline PR & 657 & 75 & 29,4 & 90 & 25 & 258 & 20 \\
PO & 2903 & 73 & 31 & 52 & 30 & 256 & 22 \\
FD & 5958 & 68 & 33,4 & 30 & 60 & 256 & 25 \\
RO & 2648 & 57 & 34,3 & 40 & 15 & 256 & 9 \\
IR & 4667 & 63 & 32,2 & 10 & 30 & 256 & 10 \\
RF & 7500 & 61 & 34,8 & 0 & 95 & 256 & 5 \\
WW & 2800 & 64 & 34,3 & 80 & 91 & 256 & 35 \\
MF & 110 & 69 & 29,3 & 100 & 50 & 257 & 30 \\
FE & 4490 & 73 & 31,8 & 25 & 80 & 256 & 15 \\
\hline
\end{tabular}




\section{Data collection}

Data were collected using direct visual observation methods. A preliminary study was conducted with seven observations until no additional species were found. In the second and third observations, it was found that each addition of observation one species was found. Conversely, on the fourth, fifth, sixth, and seventh observation, no new species were found.

Adult dragonflies were captured using insect nets at each observation with 5 replications. Catching dragonflies was carried out at two time periods of each replication, namely morning from 09.00-11.00 AM, and afternoon from 14.00-16.00 PM Central Indonesian Time (+ 8 GMT). The number of dragonfly samples was determined based on the average of all observations. The sample of dragonfly was put in a plastic bag, and preserved using $70 \%$ alcohol. Identification was carried out at the Biology Laboratory, Mataram University, Indonesia. Species identification was based on Orr and Hamalainen (2003), and Kosterin (2014).

\section{Data analysis}

Species richness was determined based on the number of species found in the study area (Quisil 2013). The assessment of conservation priority of dragonfly species was determined using the following criteria: (i) species endemicity (SE), using the indicator of the geographical distribution only in local, regional or national; (ii) population status (PS), using the indicator of population size that consists of a small natural population, which declines drastically, and vulnerable; (iii) habitat condition (HC), using the indicator of the suitable habitat that running low in extent, suitable habitat is decreasing, or the suitable habitat is sufficiently available and stable; (iv) threat (T), using the indicator of the species suffers serious damage due to hunting, trade, culture, and agriculture; (v) the status of species management (SSM), using the indicator of the presence or absence of management plan and activities for the species. Any species found in the observation will be scored base on criteria referring to Annex 1 of Regulation No. P.57/Menhut-II/2008 for the insect group. Species that have the highest number of scores out of the five criteria will be assigned as conservation priority species. The score was determined through a Focus Group Discussion (FGD) with five experts related to the scoring criteria. The score for each species was determined based on the percentage of the opinion from the experts.

\section{RESULTS AND DISCUSSION}

\section{Species richness}

There were 18 species of dragonflies found in the Suranadi Ecotourism Area, belonging to 2 suborders, namely Anisoptera and Zygoptera. One species, Pseudagrion pilidorsum declaratum, is an endemic species. The suborder Anisoptera was represented by two families, namely Aeshnidae and Libellulidae. The suborder Zygoptera was represented by three families, namely Chlorocyphidae, Coanagrionidae and Platycnemididae. Although represented by more families, the number of species from the suborder of Anisoptera was higher than that of the suborder of Zygoptera. Among the Anisoptera, the Libellulidae family consisted of 12 species, while the Aeshnidae family had only species (Figure 2.A). In Zygoptera, the family with the highest species richness was Coenagrioniddae with a total of 3 out of 5 species from this suborder (Figure 2.B).

Based on habitat type, the highest species richness was found in waterways with 17 species, while the middle forest habitat had the lowest species richness with two 2 species. Species richness in other habitats ranged from 5 to 16 species (Figure 3). Two species, namely Diplacodes trivialis and Orthetrum sabina from the Libellulidae family, were found in all habitat types. The species Libellago lineata from the Chlorocyphidae family, and Gynacantha subinterrupta from the Aeshnidae family were only found in one type of habitat, namely waterways.

During the observation, 764 specimens were recorded with 573 specimens belonged to the Anisoptera suborder and 191 specimens from the Zygoptera suborder. Among the suborder Anisoptera, the family Libellulidae was the most dominant with a total of 570 specimens. In the suborder Zygoptera, the family Coenagrionidae was the most dominant with a total of 149 specimens. The most abundant species was $O$. sabina with a total of 201 specimens, followed by Neurothemis ramburii with 108 specimens and Pantala flavescens with 101 specimens. Despite having lower species richness than waterways, the irrigation habitat had the most abundant dragonflies with 204 specimens. The detailed information is presented in Table 2 .

\section{Conservation priorities}

All dragonfly species found in the Suranadi Ecotourism Area have wide geographical distribution and none is endemic except $P$. pilidorsum declaratum. This species is only recorded to occur in East Java area and Lesser Sunda Islands (https://inaturalist.laji.fi/taxa/843602-Pseudagrionpilidorsum-declaratum). Based on Annex 1 of Regulation No. P.57/Menhut-II/2008, this species is categorized regional endemic with a calculated score of 20 in SE criteria. All species have not received adequate attention from the management aspect. Based on the total score from 18 species found in the Suranadi Ecotourism Area, there are 3 species, namely $P$. pilidorsum declaratum, L. lineata, and $G$. subinterrupta had the highest total scores (Table 3) so they are assigned as priority species for conservation (Figure 4). 

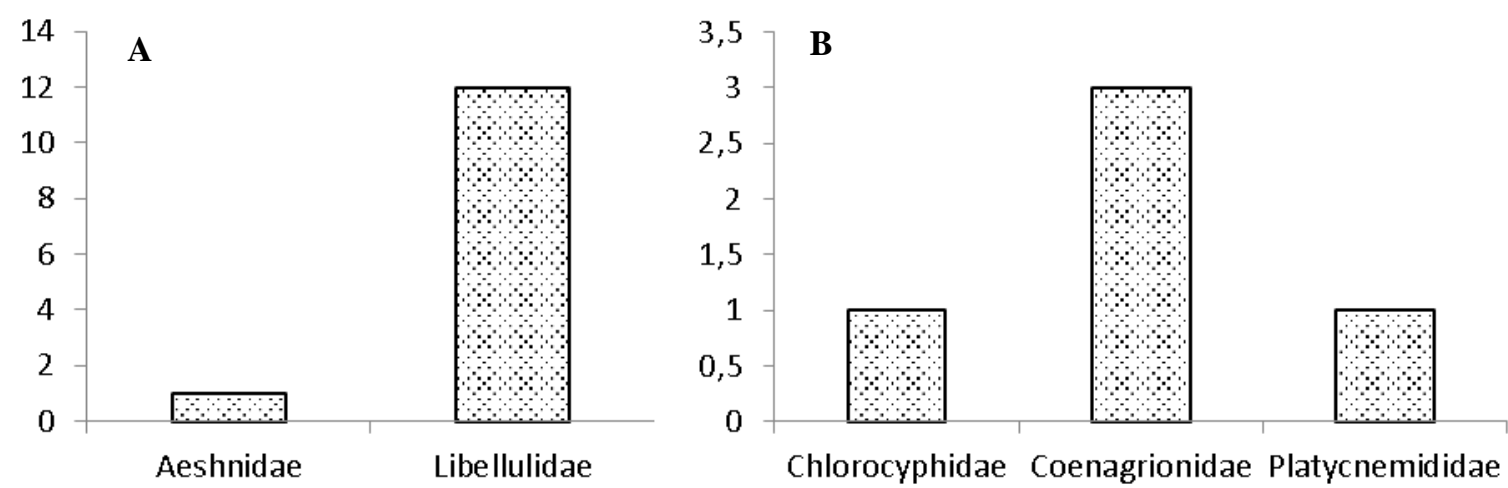

Figure 2. Species richness of dragonflies by family in suborders of Anisoptera (A) and Zygoptera (B) in the Suranadi Ecotourism Area, Lombok, Indonesia

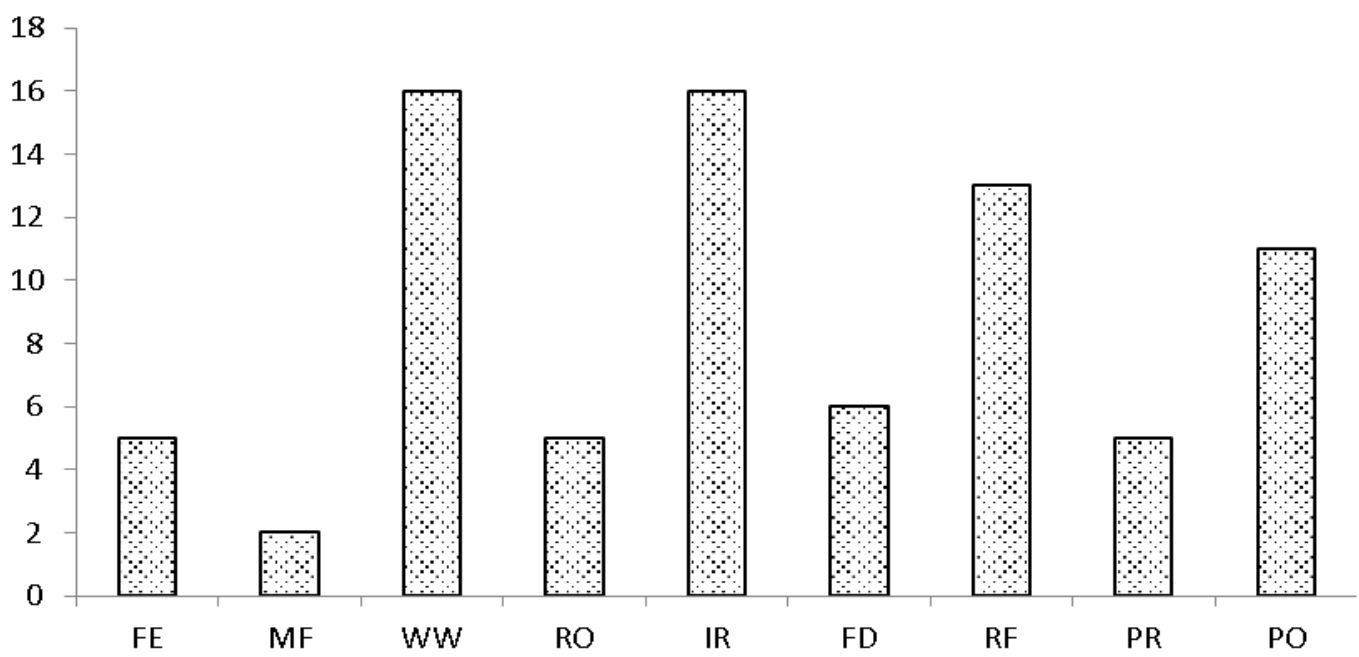

Figure 3. Species richness of dragonflies in each habitat types in the Suranadi Ecotourism Area, Lombok, Indonesia: FE: forest edges, MF: middle forest, WW: waterway, RO: roads, IR: irrigation, FD: fields, RF: rice fields, PR: Parks, and PO: pond

Table 2. The average number of dragonfly individuals across species and habitat types in the Suranadi Ecotourism Area, Lombok, Indonesia

\begin{tabular}{|c|c|c|c|c|c|c|c|c|c|c|c|c|}
\hline \multirow{2}{*}{ Suborder } & \multirow{2}{*}{ Familly } & \multirow{2}{*}{ Species name } & \multicolumn{9}{|c|}{ Average number of dragonflies in each habitat } & \multirow{2}{*}{$\Sigma$} \\
\hline & & & FE & MF & WW & RO & IR & FD & RF & $\mathbf{P R}$ & PO & \\
\hline \multirow[t]{5}{*}{ Zygoptera } & Chlorocyphidae & Libellago lineata & 0 & 0 & 2 & 0 & 0 & 0 & 0 & 0 & 0 & 2 \\
\hline & Coenagrionidae & Pseudagrion pilidorsum declaratum & 0 & 0 & 21 & 0 & 38 & 0 & 5 & 0 & 2 & 66 \\
\hline & & Pseudagrion pruinosum & 0 & 0 & 25 & 0 & 26 & 0 & 4 & 0 & 2 & 57 \\
\hline & & Agriocnemis femina & 0 & 0 & 12 & 0 & 7 & 0 & 2 & 0 & 4 & 25 \\
\hline & Platycnemididae & Copera marginipes & 0 & 0 & 17 & 0 & 19 & 0 & 3 & 0 & 2 & 41 \\
\hline \multirow[t]{13}{*}{ Anisoptera } & Aeshnidae & Gynacantha subinterrupta & 0 & 0 & 3 & 0 & 0 & 0 & 0 & 0 & 0 & 3 \\
\hline & Libellulidae & Diplacodes trivialis & 6 & 1 & 2 & 5 & 4 & 7 & 5 & 6 & 5 & 41 \\
\hline & & Lathrecista asiatica & 0 & 0 & 5 & 0 & 4 & 0 & 0 & 0 & 0 & 9 \\
\hline & & Neurothemis terminata & 0 & 0 & 4 & 0 & 3 & 0 & 0 & 0 & 0 & 7 \\
\hline & & Neurothemis ramburii & 2 & 0 & 31 & 2 & 52 & 2 & 7 & 4 & 8 & 108 \\
\hline & & Orthetrum chrysis & 3 & 0 & 23 & 3 & 14 & 2 & 5 & 1 & 3 & 54 \\
\hline & & Orthetrum sabina & 51 & 2 & 17 & 15 & 20 & 53 & 23 & 9 & 11 & 201 \\
\hline & & Pantala flavescens & 3 & 0 & 4 & 7 & 2 & 15 & 56 & 8 & 6 & 101 \\
\hline & & Trithemis festiva & 0 & 0 & 4 & 0 & 7 & 0 & 0 & 0 & 2 & 13 \\
\hline & & Zyxomma obtusum & 0 & 0 & 5 & 0 & 1 & 0 & 3 & 0 & 0 & 9 \\
\hline & & Zyxomma petiolatum & 0 & 0 & 2 & 0 & 2 & 0 & 2 & 0 & 0 & 6 \\
\hline & & Crocothermis servilia & 0 & 0 & 0 & 0 & 4 & 0 & 8 & 0 & 2 & 14 \\
\hline & & Acisoma panorpoides & 0 & 0 & 0 & 0 & 1 & 1 & 2 & 0 & 3 & 7 \\
\hline$\Sigma$ & & & 65 & 3 & 177 & 32 & 204 & 80 & 130 & 28 & 50 & 764 \\
\hline
\end{tabular}

Note: FE: forest edges, MF: middle forest, WW: waterway, RO: roads, IR: irrigation, FD: fields, RF: rice fields, PR: Parks, and PO: pond 

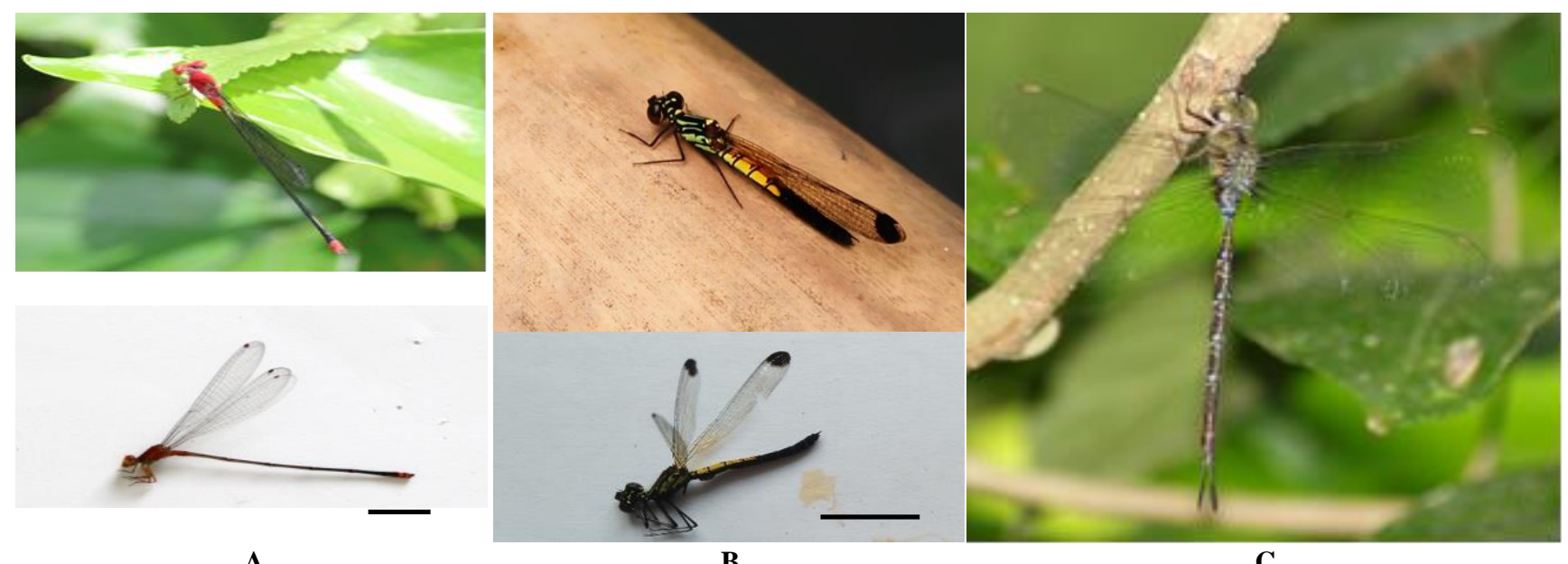

A

B

C

Figure 4. Conservation priority dragonflies species in Suranadi Ecotourism Area, Lombok, Indonesia. A. Pseudagrion pilidorsum declaratum B. Libellago lineata C. Gynacantha subinterrupta. Bar $=1 \mathrm{~cm}$

Table 3. Dragonfly species for conservation priority in the Suranadi Ecotourism Area, Lombok, Indonesia

\begin{tabular}{lccccccc}
\hline \multirow{2}{*}{ Species } & \multicolumn{9}{c}{ Criterion value } & Tota \\
\cline { 2 - 6 } & SE & PS & HC & T & SSM & $\mathbf{I}(\boldsymbol{\Sigma})$ \\
\hline Libellago lineata & 5 & 15 & 10 & 10 & 10 & 50 \\
Pseudagrion & 20 & 5 & 10 & 10 & 10 & 55 \\
pilidorsum declaratum & & & & & & \\
Pseudagrion pruinosum & 5 & 5 & 10 & 5 & 10 & 35 \\
Agriocnemis femina & 5 & 5 & 10 & 5 & 10 & 35 \\
Copera marginipes & 5 & 5 & 10 & 5 & 10 & 35 \\
Gynacantha subinterrupta & 5 & 15 & 5 & 10 & 10 & 45 \\
Diplacodes trivialis & 5 & 5 & 5 & 5 & 10 & 30 \\
Lathrecista asiatica & 5 & 10 & 10 & 5 & 10 & 40 \\
Neurothemis terminata & 5 & 5 & 10 & 5 & 10 & 35 \\
Neurothemis ramburii & 5 & 5 & 10 & 5 & 10 & 35 \\
Orthetrum chrysis & 5 & 5 & 10 & 5 & 10 & 35 \\
Orthetrum sabina & 5 & 5 & 5 & 5 & 10 & 30 \\
Pantala flavescens & 5 & 5 & 5 & 5 & 10 & 30 \\
Trithemis festiva & 5 & 10 & 10 & 5 & 10 & 40 \\
Zyxomma obtusum & 5 & 5 & 10 & 5 & 10 & 35 \\
Zyxomma petiolatum & 5 & 5 & 10 & 5 & 10 & 35 \\
Crocothermis servilia & 5 & 5 & 10 & 5 & 10 & 35 \\
Acisoma panorpoides & 5 & 15 & 5 & 5 & 10 & 40 \\
\hline Note SE: Specis
\end{tabular}

Note: SE: Species endemicity, PS: Population status, HC: Habitat condition, T: Threat, SSM: Status of species management

\section{Discussion}

The richness of dragonfly species in the Suranadi Ecotourism Area consisted of 18 species which was dominated by the Libellulidae and Coenagrionidae families (Figure 2). This number is around $46.15 \%$ of the total of 39 species richness found in Lombok Island based on observations in late February 2014 (Kosterin 2014). At a local scale, the species richness of dragonflies in the Suranadi Ecotourism Area is higher than that found in rice fields around Denpasar (Suartini and Sudatri 2019). However, this species richness is lower than that found in the West Bali National Park with 26 species (Wijayanto et al. 2016). There were 46 species of dragonflies found
(Potapov et al. 2020). In general, the species richness of dragonflies in the Lesser Sunda Islands (including Lombok) tends to be lower than in other regions (Koneri et al. 2020; Rohman et al. 2020; Sugiman et al. 2020).

Based on Figure 3, the habitat type that had the highest species richness is the waterway and irrigation. The presence of water in these habitats is the key factor because water is an ideal place for oviposition and larval habitat (Luke et al. 2017). Two other habitat types classified as aquatic habitats, namely rice fields and pond, had higher species richness than terrestrial habitats. Cumulatively, all dragonfly species in the Suranadi Ecotourism Area were found in the aquatic habitats. As the habitat type with the highest species richness, a total of 16 species were found in the waterway. On the other hand, two species that were absent in the waterway, namely Crocothermis servilia and Acisoma panorpoides, were found in irrigation, rice fields and pond. A. panorpoides had a wider distribution because apart from the three aquatic habitats, this species was also found in the terrestrial habitats. However, the number of individuals of A. panorpoides was smaller than C. servilia.

The higher species richness in waterway compared to three other aquatic habitats is due to the relatively better quality of water resources. The water in waterways is originated from springs, and is better preserved because it is located in a conservation area. Conversely, water in irrigation, rice fields and pond are contaminated by organic and inorganic waste, chlorine, and detergents. These chemical substances have negative impacts on dragonflies (Gómez-Anaya et al. 2017; Mansoor 2017; Ann et al. 2020).

Environmental conditions and resource availability have impacted not only species richness, but also the number of individuals. Dragonfly individuals were most commonly found in irrigation, waterways and rice field habitats (Table 2). Three species that contributed the most to the number of individuals and became the dominant species were $O$. sabina, $N$. ramburii, and $P$. flavescens. This finding suggests that the habitat types in the Suranadi 
Ecotourism Area are more suitable for the three species than for the other 15 species. Koneri et al. (2020) found that the number of individuals of the $O$. sabina and $P$. flavescens species increased along with reduced canopy. These two species are generally found to be abundant in open areas despite disturbances in the form of human activity (Leksono et al. 2017; Perez and Bautista 2020; Rohman et al. 2020). This proves that they are habituated to these anthropogenic environments. N. ramburii was found in almost all habitat types but the highest number of individuals was in irrigation where the tree canopy was limited.

Based on the highest score of 5 criteria of conservation priority, there were three dragonfly species considered to have conservation priority, namely $P$. pilidorsum declaratum, L. lineata and G. subinterrupta (Table 3). In the Suranadi Ecotourism Area, they were found in few habitat types in a small number of individuals. Even, $L$. lineata and $G$. subinterrupta were only found in the waterway habitat with only 2 and 3 individuals, respectively. The physical, chemical and biological conditions of the habitat where $L$. lineata and $G$. subinterrupta found had light intensity of $2800 \mathrm{Cd}$, humidity $64 \%$, air temperature $34.3^{\circ} \mathrm{C}$, tree canopy $80 \%$, herbaceous plant cover $91 \%$, altitude $256 \mathrm{~m}$ asl, and the highest number of plant species, namely 35 species. $P$. pilidorsum declaratum was found in several habitats with varying conditions.

Despite having the highest score for conservation priority, Pseudagrion pilidorsum declaratum was found in four aquatic habitat types, namely waterways, irrigation, rice fields and ponds. This species can survive in a variety of habitat conditions. During observations in the Suranadi Ecotourism Area, this species was found in habitats with humidity ranging from $61 \%-73 \%$, air temperature 31 $34.8^{\circ} \mathrm{C}$, tree canopy $0-80 \%$, herbaceous plant cover 30 $95 \%$, altitude $256 \mathrm{~m}$ asl. and the number of plants 5-35 species. Its activities were around water bodies, flying low around herbaceous plants, or perching on branches or leaves with a height of less than 1 meter. This species can also be found in small river estuary habitats with edges of gravel or sand and trees, and rivers in gardens and forests with rocky ground (Kosterin 2014).

Unlike $P$. pilidorsum declaratum, Libellago lineata was only found in the waterway. We found this water bodies species at the end of the dam bordering the road, commonly perching on a floating banana stem. This species can also be found perching on shrubs, grass with tree vegetation (Zada et al. 2016). In the Mahaka River, South Sulawesi, L. lineata can survive in habitats with temperature conditions of $32.59^{\circ} \mathrm{C}$ and humidity of $46.14 \%$ (Nuraeni et al. 2019). This temperature is lower than that in the waterway in our study. Viewed from water quality, this species is adaptive to low quality water (Jacob and Manju 2016). L. lineata can also habituate anthropogenic factors because it is found in parks (Hermawan and Fitriana 2015).

Like L. lineata, G. subinterrupta was found only in waterway. This species is the only dragonfly from the Aeshnidae family in the Suranadi Ecotourism Area. Abdillah et al. (2019) found G. subinterrupta in Sumber
Mangli, Kediri, East Java in river habitats with temperature conditions above $25^{\circ} \mathrm{C}$ and humidity above $80 \%$. This species can habituate to anthropogenic factors because it is found in parks, namely pond habitats and wetlands (Ngiam and Davison 2016). Other habitat characteristics that can support G. subinterrupta are pond with a high depth, and a ditch with a shallow muddy bottom. On the edge of ponds and trenches, there is high herbaceous plant cover and dense trees (Kosterin 2014).

The three species of conservation priorities, i.e. $L$. lineata, $P$. pilidorsum declaratum, and G. subinterrupta, have different ecological niches and habitat types, but some are in scope. Conservation efforts need to consider these factors. The conservation of the three priority species and dragonflies in general in this area is important because ecologically they play an important role in preserving nature which is the area for tourist destinations. Preserved nature has a positive impact on the sustainability of the economy of people who depend on tourism activities. From an educational aspect, dragonflies can be a source of learning at both the primary, secondary and higher education levels. This research itself contributes to provide important information for developing conservation and ecotourism strategies in Suranadi.

In conclusion, the species richness of dragonflies in the Suranadi Ecotourism Area of Lombok, Indonesia consisted of 18 species from 5 families (Chlorocyphidae, Coanagrionidae, Platycnemididae, Aeshnidae and Libellulidae) suborder Anisoptera and Zygoptera with three conservation priority species namely $P$. pilidorsum declaratum, L. lineata, and G. subinterrupta.

\section{ACKNOWLEDGEMENTS}

We thank the Directorate General of Higher Education (Dirjen Dikti), Ministry of Education and Culture, Indonesia for research funding. We also express our gratitude to the BON Team for their contribution during data collection in the field.

\section{REFERENCES}

Abdillah M, Prakarsa TBP, Tyastirin E. 2019. Odonata diversity at Sumber Clangap and Sumber Mangli Puncu Village Subdistrict of Puncu District of Kediri. Biodjati 4: 236-243. DOI: 10.15575/biodjati.v4i2.4823. [Indonesian]

Ann M, Perron C, Pick FR. 2020. Water quality effects on dragonfly and damselfly nymph communities: A comparison of urban and natural ponds. Environ Pollut 263: 1-13. DOI: 10.1016/j.envpol.2020.114472.

Arbeiter S, Schnepel H, Uhlenhaut K, Bloege Y, Schulze M, Hahn S. 2014. Seasonal shift in the diet composition of european bee-eaters merops apiaster at the northern edge of distribution. Ardeola 61: 161170. DOI: 10.13157/arla.61.1.2014.161.

Gómez-anaya JA, Novelo-gutiérrez R, Astudillo-Aldana MR. 2017. Effect of domestic and coffee mill discharges on the water quality and the Odonata (Insecta) larval diversity in a mountain cloud forest stream in Veracruz, Mexico. Rev Mex Biodivers 88: 372-380. DOI: 10.1016/j.rmb.2017.03.004.

Hermawan AS, Fitriana N. 2015. Diversity and fluctuations of Odonates in BSD City Park, South Tangerang, Banten. Pros Sem Nas Masy Biodiv Indon 8: 1795-1801. DOI: 10.13057/psnmbi/m010808. 
Jacob S, Manju EK. 2016. Potential of Odonate (dragonflies and damselflies) diversity as a bioindicator of water quality. Intl J Sci Res 5: 2033-2036.

Koneri R, Nangoy M, Maabuat PV. 2020. Composition and diversity of dragonflies (Insecta: Odonata) in Tunan Waterfall Area, North Minahasa, North Sulawesi, Indonesia. Pak J Zool 52(6): 1-10. DOI: 10.17582/journal.pjz/20181214071225.

Kosterin OE. 2014. Odonata briefly observed on the islands of Bali and Lombok, Lesser Sundas, Indonesia, in late February 2014. International Dragonfly Fund (IDF )- Report 74: 1-48.

Leksono AS, Feriwibisono B, Arifianto T, Pratama AF. 2017. The abundance and diversity of Odonata along an altitudinal gradient in East Java, Indonesia. Entomol Res 47 (4): 1-8. DOI: 10.1111/17485967.12216.

Linares AM, Maciel-Júnior JAH, de Mello HES, Leite FSF. 2016. First report on predation of adult anurans by Odonata larvae. Salamandra 52: $42-44$.

Luke SH, Dow RA, Butler S, Vun Khen C, Aldridge DC, Foster WA, Turner EC. 2017. The impacts of habitat disturbance on adult and larval dragonflies (Odonata) in rainforest streams in Sabah, Malaysian Borneo. Freshw Biol 62: 491-506. DOI: 10.1111/fwb.12880.

Mafuwe K, Moyo S. 2020. Dragonfly (Odonata) community structure in the Eastern Highlands Biodiversity Hotspot of Zimbabwe: Potential threats of land use changes on freshwater invertebrates. Int J Odonatol 23(3): 1-14. . DOI: 10.1080/13887890.2020.1768156.

Mansoor R. 2017. Do herbaceous planticide effects on Odonata larvae, depend on their location of origin? An ecotoxicological study using Glyphosate. [Thesis]. Halmstad University, Halmstad. [Sweden].

May ML. 2019. Odonata: Who they are and what they have done for us lately: Classification and ecosystem services of dragonflies. Insects 62: 1-17. DOI: 10.3390/insects10030062.

Nasirian H, Irvine KN. 2017. Odonata larvae as a bioindicator of metal contamination in aquatic environments: Application to ecologically important wetlands in Iran. Environ Monit Assess 189: 189:436. DOI: $10.1007 / \mathrm{s} 10661-017-6145-6$.

Ngiam RWJ, Davison GWH. 2016. A checklist of dragonflies in Singapore Parks (Odonata: Anisoptera, Zygoptera). Nat Sing 4: 349353.

Nuraeni S, Budiaman, Yaspeta S. 2019. Identification of dragonfly and damselfly species around Mahaka river, Hasanuddin university teaching forest. IOP Conf Ser: Earth Environ Sci 343: 1-9. DOI: 10.1088/1755-1315/343/1/012052.

Oliveira-Junior J, Juen L. 2019. The Zygoptera/Anisoptera ratio (Insecta: Odonata): A new tool for habitat alterations assessment in Amazonian streams. Neotrop Entomol 48: 552-560. DOI: 10.1007/s13744-019 00672-x

Orr A, Hamalainen M. 2003. A Guide to the Dragonflies of Borneo Their Identification and Biology. Natural History Publications, Kinabalu (Borneo).
Peraturan Bupati Lombok Barat No. 41 tentang Kawasan Desa Wisata. 2016. Pemerintah Daerah Kabupaten Lombok Barat, Gerung. [Indonesian]

Perez ESN, Bautista MG. 2020. Dragonflies in the city: Diversity of Odonates in urban Davao, Philippines. J Agric Sci Technol 10: 12-19. DOI: $10.17265 / 2161-6256 / 2020.01 .002$.

Potapov GS, Kolosova YS, Gofarov MY, Bolotov IN. 2020. Dragonflies and damselflies (Odonata) from Flores Island, Lesser Sunda Archipelago: New occurrences in extreme environments and an island-level checklist of this group. Ecol Montenegrina 25: 5-25. DOI: $10.37828 / \mathrm{em} .2020 .35 .2$

Quisil SJC, Arreza JDE, Nuneza OM, Villanueva RJT. 2013 Species richness of Odonata in Lanuza and San Agustin, Surigao del Sur, Philippines. AES Bioflux 5(3):245-260.

Rohman A, Sulistyono S, Nuryati W, Arifandy A, Setiyanto A. 2020. Dragonflies in Bawean Island Nature Reserve, Indonesia. Borneo J Res Sci Technol 10: 45-50. DOI: 10.33736/bjrst.2022.2020.

Rüppell G, Hilfert-Rüppell D, Schneider B, Dedenbach H. 2020. On the firing line-interactions between hunting frogs and Odonata. Int $\mathrm{J}$ Odonatol 23: 199-217. DOI: 10.1080/13887890.2020.1733328.

Šigutováa H, Šipoš J, Dolný A. 2019. A novel approach involving the use of Odonata as indicators of tropical forest degradation: When family matters. Ecol Indic 104: 229-236 10.1016/j.ecolind.2019.05.001.

Suartini NM, Sudatri NW. 2019. Species of dragonflies (Odonata order) for rice plantations in some rice field around Denpasar, Bali Simbiosis 7: 23-28. DOI: 10.24843/JSIMBIOSIS.2019.v07.i01.p05.

Sugiman U, Atmowidi T, Priawandiputra W. 2020. Community structure and habitat characteristics of dragonflies (Odonata) in tropical lowland forest of Ujung Kulon National Park J Entomol Zool Stud 8: 251-258. www.entomoljournal.com.

Ting D, Huai-jian L, Lei S. 2018. Odonata aquatic insects as bioindicators in water quality evaluation of Dianchi Lake riparian wetland. $\mathrm{J}$ For Res 31: 145-152. DOI: 10.13275/j.cnki.lykxyj.2018.05.020.

Weterings R, Umponstira C, Buckley HL. 2015. Predation rates of mixed instar Odonata naiads feeding on Aedes aegypti and Armigeres moultoni (Diptera: Culicidae) larvae. J Asia-Pacific Entomol 18: 1-8. DOI: 10.1016/j.aspen.2014.10.008.

Wijayanto AG, Nafisah NA, Laily Z, Zaman MN. 2016. Inventarisasi capung (insecta: Odonata) dan variasi habitatnya di Resort Tegal Bunder dan Teluk Terima Taman Nasional Bali Barat (TNBB). Seminar Nasional Pendidikan dan Saintek 2016: 427-434.

Zada N, Farid A, Zia A, Saeed M, Khan SM, Khan A, Khan IA, Fazlullah, Badshah T. 2016. Damselflies (Odonata: Zygoptera) fauna of District Buner, Khyber Pakhtunkhwa, Pakistan. J Entomol Zool Stud 4: 491495. 